\title{
WAGE EXPECTATIONS IN LIGHT OF HUMAN CAPITAL MEASUREMENT THEORY
}

\begin{abstract}
The aim of the paper is to examine the consistency between wage computations using an economic constant versus expected wages. Furthermore, the research compares the legal real minimum wage and wages computed in accordance with human capital theory. The author builds an econometric model of wages as a function of two variables. In addition, in order to facilitate the reader's understanding of the article, a human capital measurement model is presented along with a measurement of fair wages. The results show that the human capital model is useful as a comprehensive measure of value and present a technique for its reliable measurement. The paper's findings may make a significant contribution to the debate on how to measure human capital properly.
\end{abstract}

Keywords: human capital model, economic constant, wages, minimum wages, wage expectations.

\section{Introduction. Labourism as an Original Scientific Research Programme}

Research in the area of human capital (in light of its abstract nature as the ability to do work and the existing economic constant of potential growth) has been carried out for over fifteen years. The first article in this area was published in 1997 (Dobija 1997). Since then, there have been many publications in which authors have developed issues in the area of human capital measurement theory, the theory of fair wages for work, the theory of basic and premium wages, labour productivity theory, and the theory of money and economy without deficit (Dobija 2011a, Kozioł 2010b, Kurek 2008). These theories are a consequence of the implementation of the human capital measurement model and understanding the relationships between the categories of capital, labour, and fair wages. 
According to T. Schultz's theory and the theories of other scholars in the field of human capital research in light of investing in people, we do not find effective attempts to understand the nature of capital. In accordance with these approaches, capital is "undoubtedly a good thing" (Dobija 2011c, p. 120), but the scientific formulation is missed here. This is the traditional approach in economic research, where the question of the nature of the capital is not resolved but just postponed. This is the reason for the lack of compliance in these studies between certain key economic categories.

Failure to fully understand the principle of duality is an obstacle to understanding the nature of capital. Therefore, there is insufficient knowledge of the basic connections between capital, labour, and wages. Nevertheless, these concepts are central for economics. This fact affects the majority of economic theories, for which the solution of basic problems in the "capital - labour - equitable remuneration (fair wages)" triad is a key question (Dobija 2011a, pp. 143-44).

Nowadays, there is every reason to conclude that the original academic research programme in the sphere of human capital has been formed as a result of economic research that began in the 1990s. From year to year, these studies become more and more developed and a wider range of issues finds proper theoretical explanation. What is more, such open economic questions as money, credit, and budget deficit are elucidated differently within the new research programme. One of the last publications of M. Dobija (Dobija 2011b) has signalled a fundamental changes in economic thought. There are signs that the new academic research programme, proposed by the author, is gradual in terms of the methodology of I. Lakatos. In this programme, capital, labour, and fair wages constitute an inseparable triad (as illustrated in Fig. 1), in which labour is presented as a capital transfer to labour products.

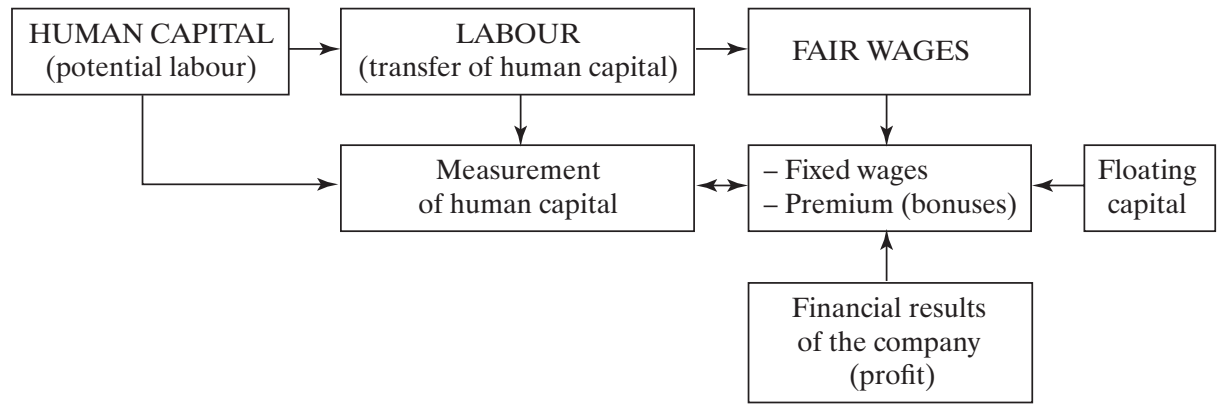

Fig. 1. The Triad: Capital - Labour - Fair Wages

Source: author's own research. 
The research programme is based on an understanding of the nature of capital as the ability to work, and on an advanced study of its theory. It is precisely this fact which is most important in the programme.

\section{The Human Capital Measurement Model}

Human capital is a natural attribute of an employee. Its explanation is provided by human capital theory models. To determine each person's needed capital, expenditures such as the cost of living, education, experience, and capital expenditures on human work, as in the case of professors, must be identified. Identification of these expenditures and definition of the capital growth function as a result of acquired experience leads to the well-known and well-verified human capital model that was shown in many previous surveys (Dobija 2007, 2009, 2011a, Dobija (ed.) 2010, Kurek 2008, 2010, 2011, 2012, Kozioł 2007, 2010a).

Human capital is a function of many variables, where: $k$ - monthly maintenance costs, $t$ - the time variable, $T$ - the length of a professional career (in years), and $p$ - the economic constant of potential growth. The formula shown below represents the simplest model of human capital:

$$
H(k, t, T, p)=K,
$$

where $H(k, t, T, p)$ - the value of human capital, $K$ - the capitalised cost of living with rate $p$.

The expanded model contains more variables associated with professional education and obtained work experience. Its character can be described as follows (Cieślak \& Dobija 2007, pp. 5-24):

$$
H(T, p)=(K+E) \cdot[1+Q(T)],
$$

where $H(T, p)$ - the value of capital of a person with $T$ years of experience, $K$ - the capitalised costs of living, $E$ - the capitalised costs of education, $Q(T)$ - the growth factor experience after $T$ years of work.

This model can also be presented in additive form:

$$
H(T)=K+E+D(T),
$$

where $D(T)$ is the capital of work experience after $T$ years and $D(T)=$ $=H(0) \cdot Q(T)$, where $D(0)=0$. This model is more convenient for analysing and explaining the wages. 
The human capital model can be supplemented with the capital creativity ratio $(\mathrm{Cr})$ or variable $\mathrm{Ui}$, which is used in the human capital measurement model of university professors (Koziol 2010a). It sets the level of capitalised costs of getting another academic degree (where $t$ is the number of years from the date of receiving the degree to the measurement date). These models are shown in Table 1.

Table 1. The Human Capital Measurement Models of Employees

\begin{tabular}{c|c|l}
\hline No. & Human capital measurement model & \multicolumn{1}{c}{$\begin{array}{c}\text { Characteristics of the human capital } \\
\text { measurement model }\end{array}$} \\
\hline 1 & $H(T)=K$ & $\begin{array}{l}\text { The human capital of an employee who } \\
\text { does not have a university degree or } \\
\text { work experience (consists only of the } \\
\text { capitalised costs of living) }\end{array}$ \\
\hline 3 & $H(T)=K+E$ & $\begin{array}{l}\text { The human capital of an employee who } \\
\text { has a university degree (there is an } \\
\text { additional variable - the capitalised costs } \\
\text { of education) }\end{array}$ \\
\hline 4 & $H(T)=(K+E) \cdot(1+Q(T))$ & $\begin{array}{l}\text { The human capital of an employee who } \\
\text { has work experience (the rate of capital } \\
\text { growth experience depends on years of } \\
\text { professional experience, especially in the } \\
\text { first years of work) }\end{array}$ \\
\hline 5 & $H(T)=K+E+D(T)$ & $\begin{array}{l}\text { The additive form of the employee's } \\
\text { human capital model }\end{array}$ \\
\hline 6 & $H(T)=K+E+D(T)+U_{i} \cdot\left(1+Q\left(t_{i}\right)\right)$ & $\begin{array}{l}\text { The human capital of an employee who } \\
\text { has a capital of creativity }\end{array}$ \\
\hline $\begin{array}{l}\text { The human capital of university } \\
\text { years from the date of receiving the } \\
\text { degree to the measurement date) }\end{array}$ \\
\hline
\end{tabular}

Source: author's own research.

Thus, you can determine the level of human capital of each employee by using the models described in Table 1 and this amount will be the basis for determining fair wages for every employee. It should be emphasised that level of capitalisation is also important and from study it is $8 \%$ per annum (Kurek 2008, 2010, 2012, Renkas 2011). 


\section{The Data and the Regressive Model of Wage Expectations}

In October 2010, in the Volodarsk-Volynskii Employment Centre (Ukraine, Zhytomyr region), a survey was conducted in which 135 job seekers were interviewed. The survey included questions about age, number of years of education, and expected wage (Table 2). Obtaining such data makes it possible, on the basis of a large sample of interviewed people $(n=135)$, to use multiple regression and determine the relationship between age, number of years of education, and the expected wage of people registered in the Volodarsk-Volynskii Employment Centre.

The wages calculated using the model are comparable to the actual or minimum wage in Ukraine, which is defined by state law. Such kinds of comparisons indicate the level of compatibility of wages and can help to determine whether the derived econometric model can be used to calculate employees' wages.

The advantage of the research carried out at the Employment Centre is that job seekers were analysed. While those people were under pressure of unemployment and a free job market, they did not expect high wages. Their expected wages would provide them with the opportunity to support their families and maintain human capital at least at the same level. Therefore, expected wages are good material for analysing the economic constant of the growth potential.

As part of the survey, 135 respondents were interviewed. The confidence interval of the economic constant defining the level of human capital payment of respondents was obtained $(7.60-8.53 \%)$ at a confidence level of 0.95 . The average value of the constant was $8.1 \%$. As one can see, the compatibility of the human capital of people participating in the survey with their expected wage confirmed the economic constant at $8 \%$.

The data for determining the parameters of the model are derived from Table 2. The variables (age, years of education, and expected pay $(W)$ ) contain the results from the Volodarsk-Volynskii Employment Centre survey. Multiple regression was used to analyse the variables (Sobczyk 2010), and this allowed the level of employees' wages to be predicted better. The dependent variable in this example is the variable expected wage $(W)$, and the independent variables (predictors) are age and years of education.

In accordance with the principles of gradual regression, the variable years of education better describes expected pay $(W)$. So the regression equation is:

$$
Y=B_{2} X_{1}+B_{1} X_{2}+B_{0}
$$




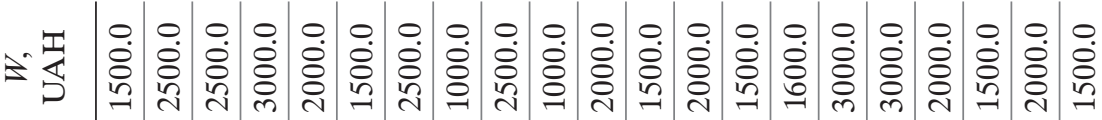

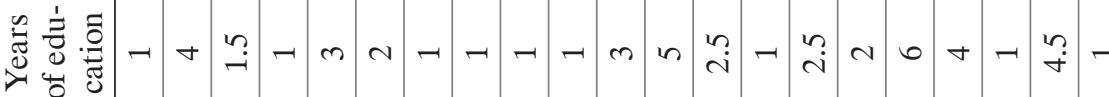

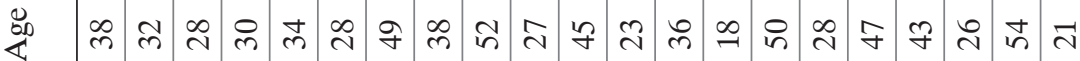

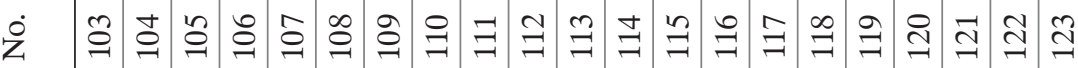

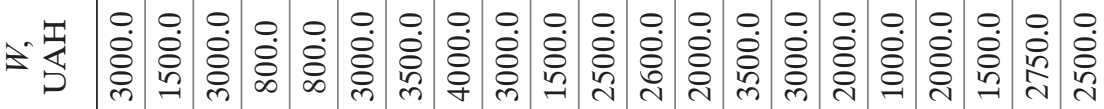

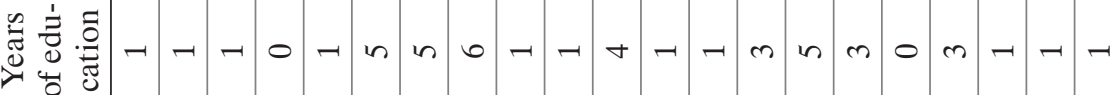

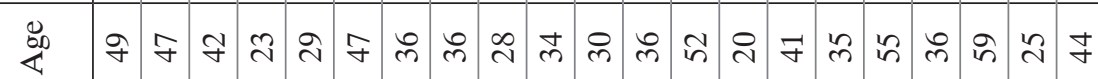

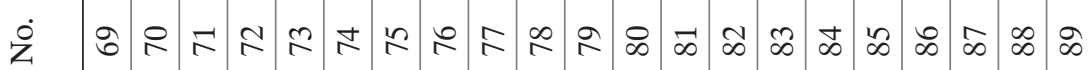

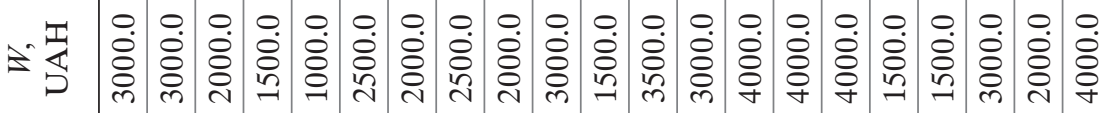

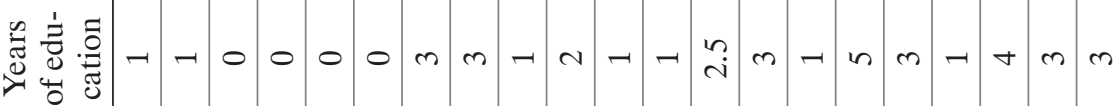

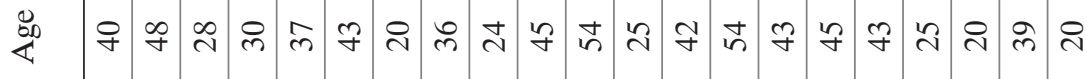
$\dot{0}$ ஸे 恣

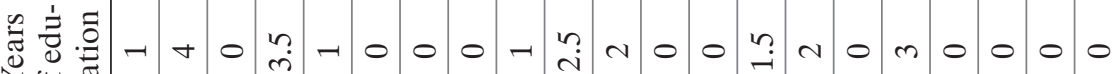
द न 光 $\succ$ फ

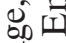

苾 m ㄴ. 


\begin{tabular}{|c|c|c|c|c|c|c|c|c|c|c|c|c|}
\hline 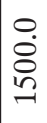 & ○. & $\begin{array}{l}0 \\
\dot{8} \\
8 \\
\dot{8}\end{array}$ & $\begin{array}{l}0 \\
\stackrel{\circ}{8} \\
\stackrel{\overbrace{}}{0}\end{array}$ & $\begin{array}{l}\stackrel{0}{0} \\
\stackrel{\leftrightarrow}{8} \\
\stackrel{\overbrace{}}{\circ}\end{array}$ & $\begin{array}{l}0 \\
\dot{8} \\
\stackrel{\circ}{2} \\
-\end{array}$ & $\begin{array}{l}0 \\
\stackrel{8}{8} \\
\stackrel{0}{n} \\
\end{array}$ & $\begin{array}{l}0 \\
\stackrel{8}{8} \\
\stackrel{\circ}{2}\end{array}$ & O. & $\begin{array}{l}0 \\
\stackrel{\circ}{\circ} \\
\stackrel{ }{0}\end{array}$ & 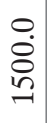 & ○. & \\
\hline$m$ & $\nabla$ & $m$ & $\nabla$ & 0 & nn & $\nabla$ & - & - & $n$ & -1 & in & \\
\hline in & $\stackrel{\mathcal{F}}{\mathcal{H}}$ & $\tilde{n}$ & 崩 & in & $\ddot{\theta}$ & ন & ก & fo & $m$ & ং্ল & ก & \\
\hline$\stackrel{さ}{\sim}$ & $\stackrel{2}{3}$ & $\stackrel{?}{\mathrm{I}}$ & $\widehat{\beth}$ & $\stackrel{\infty}{\underset{\sim}{\sim}}$ & తి & 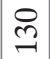 & $\vec{m}$ & $\tilde{\Omega}$ & $\stackrel{m}{m}$ & $\stackrel{\vec{m}}{\longrightarrow}$ & $\stackrel{n}{n}$ & \\
\hline @ & $\begin{array}{l}0 \\
\stackrel{8}{8} \\
\stackrel{0}{2}\end{array}$ & $\begin{array}{l}0 \\
\dot{8} \\
\stackrel{0}{n} \\
-1\end{array}$ & $\begin{array}{l}0 \\
\stackrel{\leftrightarrow}{\circ} \\
\text { ஸి }\end{array}$ & $\begin{array}{l}0 \\
\dot{8} \\
\stackrel{0}{n} \\
\end{array}$ & $\begin{array}{l}0 \\
\stackrel{8}{\circ} \\
\stackrel{\circ}{1}\end{array}$ & $\begin{array}{l}0 \\
0 \\
\dot{8} \\
\dot{0} \\
0\end{array}$ & 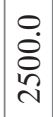 & $\begin{array}{l}0 \\
\stackrel{8}{8} \\
\stackrel{0}{n} \\
\end{array}$ & 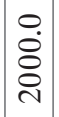 & $\begin{array}{l}0 \\
\dot{8} \\
\stackrel{0}{2} \\
\sim\end{array}$ & $\begin{array}{l}0 \\
\stackrel{8}{8} \\
\stackrel{n}{1}\end{array}$ & $\begin{array}{l}0 \\
\stackrel{0}{0} \\
\stackrel{8}{0} \\
\text { r. }\end{array}$ \\
\hline- & $\because$ & - & -1 & -1 & - & $\because$ & - & $\nabla$ & $m$ & -1 & -1 & $\sim$ \\
\hline $\mathscr{r}$ & 导 & $\hat{n}$ & $\underset{+}{\infty}$ & $\infty$ & $\underset{+}{+}$ & ले & in & $\mathscr{f}$ & $\approx$ & in & 吉 & $\approx$ \\
\hline 응 & $\bar{\sigma}$ & สู & $a$ & む゙ & $\curvearrowleft$ & ๑ & $\hat{a}$ & 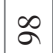 & aे & 8 & 의 & ป̂ \\
\hline $\begin{array}{l}0 \\
\stackrel{0}{\circ} \\
\stackrel{n}{n}\end{array}$ & $\begin{array}{l}0 \\
\stackrel{0}{\circ} \\
\stackrel{\circ}{2}\end{array}$ & 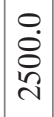 & $\begin{array}{l}0 \\
\stackrel{8}{0} \\
\stackrel{8}{0}\end{array}$ & $\begin{array}{l}0 \\
\dot{8} \\
\stackrel{0}{n} \\
\sim\end{array}$ & $\begin{array}{l}0 \\
\stackrel{8}{\circ} \\
\text { ñ }\end{array}$ & $\begin{array}{l}0 \\
\stackrel{0}{\circ} \\
\stackrel{n}{2}\end{array}$ & 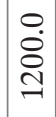 & 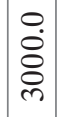 & $\begin{array}{l}0 \\
\dot{8} \\
\stackrel{\circ}{2} \\
\end{array}$ & $\begin{array}{l}0 \\
\dot{0} \\
\stackrel{0}{n} \\
-1\end{array}$ & 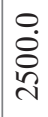 & $\begin{array}{l}0 \\
\stackrel{0}{\circ} \\
\stackrel{\circ}{2}\end{array}$ \\
\hline$\sim$ & 0 & $\sim$ & $\sim$ & $N$ & $N$ & 0 & -1 & -1 & - & 0 & - & $m$ \\
\hline กี & $\ddot{\sim}$ & $\hat{n}$ & $\bar{n}$ & in & g & $\stackrel{\searrow}{\sim}$ & $\underset{+}{\infty}$ & $\vec{n}$ & $\stackrel{m}{f}$ & $\stackrel{\sim}{\mathrm{N}}$ & fr & $\vec{\sim}$ \\
\hline in & in & $\stackrel{\infty}{\curvearrowleft}$ & in & 8 & $\overline{6}$ & $\widetilde{\sigma}$ & శె & $\vec{J}$ & 6 & 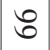 & $\widehat{6}$ & $\infty$ \\
\hline @̊. & 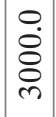 & $\begin{array}{l}0 \\
\dot{8} \\
\stackrel{0}{0} \\
\text { ते }\end{array}$ & $\begin{array}{l}0 \\
\dot{0} \\
\dot{D} \\
n\end{array}$ & $\begin{array}{l}0 \\
\dot{8} \\
8 \\
8\end{array}$ & $\begin{array}{l}0 \\
\stackrel{8}{8} \\
\stackrel{0}{0}\end{array}$ & 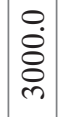 & 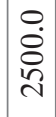 & 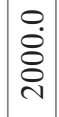 & 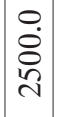 & $\begin{array}{l}0 \\
\dot{8} \\
\stackrel{8}{0} \\
\text { त. }\end{array}$ & $\begin{array}{l}0 \\
\stackrel{8}{8} \\
\stackrel{\circ}{1}\end{array}$ & $\begin{array}{l}0 \\
\dot{8} \\
8 \\
8 \\
0\end{array}$ \\
\hline 0 & $m$ & - & $r$ & 0 & 0 & $\nabla$ & $\nabla$ & - & -1 & -1 & N & -1 \\
\hline in & $\infty$ & $m$ & 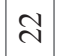 & లి & ৯े & $\hat{n}$ & 2 & ป & $\vec{v}$ & m & in & $\begin{array}{l}\infty \\
m\end{array}$ \\
\hline$\tilde{N}$ & $\ddot{\sim}$ & $\stackrel{d}{d}$ & $\stackrel{n}{d}$ & $\stackrel{\sim}{\sim}$ & $\hat{\sim}$ & $\stackrel{\infty}{\sim}$ & ৯ે & 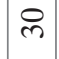 & $\bar{m}$ & $\tilde{m}$ & $m$ & ষ্ \\
\hline
\end{tabular}


The regression coefficients $\left(B_{0}, B_{1}, B_{2}\right)$ can be found in Table 3, which contains a summary of the regression. If there is no linear relationship among the variables $X_{1}, X_{2}$ and $Y$, then the directional coefficients of the regression in the population (the parameters $b_{1}$ and $b_{2}$ ) are equal to zero. Therefore, we confirm that the existence of this relationship is not direct. We test the hypothesis that the true values of the coefficients $b_{i}$ are equal to zero $\left(H_{0}: b=0\right)$, contrary to the alternative hypothesis $\left(H_{1}: b \neq 0\right)$. If during verification of the hypotheses we reject the null hypothesis in favour of the alternative one $\left(H_{1}\right)$, this means that we can use statistical methods to confirm the impact of the variables $X_{1}$ and $X_{2}$ on variable $Y$, and we can call it an important evaluation parameter. This means that variable $X$ has a significant impact on the dependent variable $Y$. To verify the hypotheses, we use the Student's $t$-test. This test is as follows:

$$
t=\frac{b_{i}}{s\left(b_{i}\right)},
$$

where $b_{\mathrm{i}}$ - the coefficient of the regression line, and $s\left(b_{\mathrm{i}}\right)-$ the standard error of the estimator $b_{\mathrm{i}}$.

Table 3. Summary of the Regression of the Dependent Variable expected wage $(W)$

\begin{tabular}{c|c|c|c|c|c|c}
\hline$N=135$ & $B^{*}$ & $\begin{array}{c}\text { The } \\
\text { standard } \\
\text { error of } B^{*}\end{array}$ & B & $\begin{array}{c}\text { The } \\
\text { standard } \\
\text { error of } B\end{array}$ & $t(132)$ & $\begin{array}{c}\text { The level } \\
\text { of } p\end{array}$ \\
\hline Free term & - & - & 1320.739 & 226.9345 & 5.819913 & 0.000000 \\
\hline Variable 2 & 0.421248 & 0.077139 & 217.394 & 39.8092 & 5.460903 & 0.000000 \\
\hline Variable 1 & 0.185028 & 0.077139 & 13.181 & 5.4952 & 2.398636 & 0.017854 \\
\hline
\end{tabular}

Source: author's own calculations.

In the last three columns of Table 3, the standard error evaluation values, $t$-test, and the level of significance are provided. The level of $p$ is the level of statistical significance for the regression coefficients. Using the calculated values from Table 3, we can suggest that for the data in Table 1, there are statistical bases for recognising that there is a linear relation between the variables, because two variables (age and years of education) are highly significant. As the value of probability $p$ in all cases is less than assumed $\alpha=0.05$, which rejects the null hypothesis $H_{0}$, we can conclude that the 
observed relations between age and years of education and expected wage are not a coincidence.

The level of beta coefficients allows us to compare the relative contribution that each independent variable makes to predicting the dependent variable. As one can see from Table 3, the most important predictor (statistically significant) is the variable years of education (variable 2). The coefficient is positive for the variable years of education. This means the greater the number of years of education, the higher the wage level.

Finally, our econometric model defines the level of the expected wage as follows:

$$
Y=13.18 X_{1}+217.39 X_{2}+1320.74
$$

where $Y$ - the employee's wage, $X_{1}$ - the employee's age, $X_{2}$ - the number of years of education.

Using the above formula, we can calculate the level of the minimum wage in Ukraine. Every person who is 18 years old and has a basic professional education deserves the minimum wage in Ukraine. For our model, let us substitute $X_{1}$ by the number 18 , and $X_{2}$ by the number 1 (one year of vocational education). Then the result is: $Y=1775.4 \mathrm{UAH}$.

\section{The Minimum Wage Comparison and Its Assessment}

The main method of testing the human capital measurement model empirically is based on the calculation of wages and their comparison with expected or actual wages. The research is particularly efficient in regard to the minimum wage, since the minimum wage is usually defined by state law. The use of econometric modelling creates additional value for comparison.

Part of the human capital of an employee is the capitalised costs of living $(K)$ until the age of consent. According to human capital theory, a wage solely calculated on the basis of cost $K$ should be equal to the minimum wage. Table 4 shows the level of the minimum wage in Ukraine, calculated on the basis of human capital theory for several periods in 2010-2011.

According to the above data about the level of the minimum wage determined on the basis of human capital theory as on 1 October 2011, we can compare this value to the level of the minimum wage determined on the basis of the econometric model.

Table 5 compares the statutory minimum wage in Ukraine with minimum wages based on human capital theory (as $8 \%$ of the human capital of an employee) and the econometric model. 


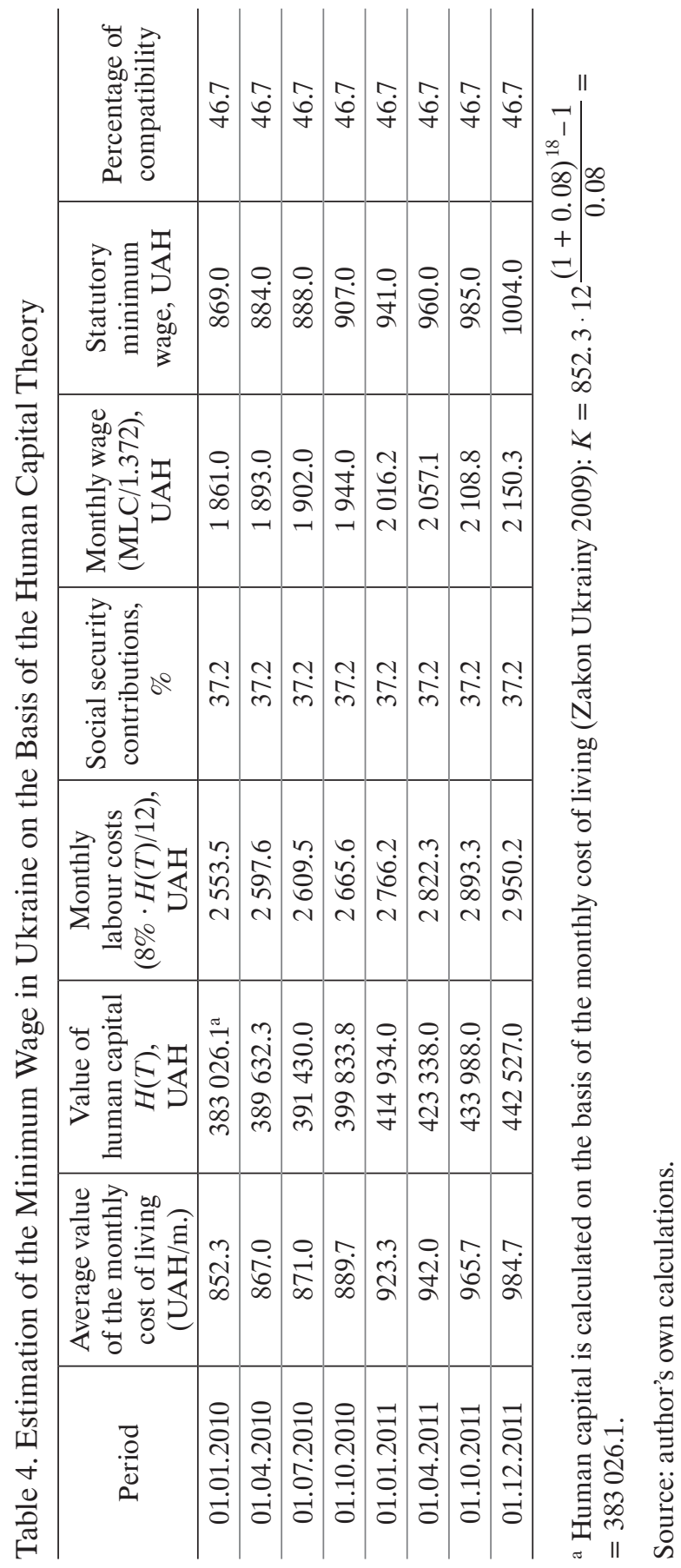


Table 5. Comparison of the Statutory Minimum Wage in Ukraine to Minimum Wages Based on Human Capital Theory and the Econometric Model (2010-2011)

\begin{tabular}{l|c|c|c|c|c}
\hline \multirow{2}{*}{ Specification } & \multicolumn{2}{|c|}{$\begin{array}{c}\text { Statutory minimum } \\
\text { wage }\end{array}$} & \multicolumn{2}{c|}{$\begin{array}{c}\text { Minimum wage } \\
\text { determined } \\
\text { on the basis of human } \\
\text { capital theory }\end{array}$} & $\begin{array}{c}\text { Minimum wage } \\
\text { determined on } \\
\text { the basis of the } \\
\text { econometric model }\end{array}$ \\
\cline { 2 - 6 } & 01.10 .2010 & 01.10 .2011 & 01.10 .2010 & 01.10 .2011 & 01.10 .2010 \\
\hline Amount in UAH & 907.0 & 985.0 & 1944.0 & 2108.8 & 1775.4 \\
\hline $\begin{array}{l}\text { Percentage } \\
\text { of compatibility }\end{array}$ & 46.7 & 46.7 & 100.0 & 100.0 & 91.3 \\
\hline
\end{tabular}

Source: author's own calculations.

As can be seen in Table 5, the level of the minimum wage calculated using the above formula is close to the level of the minimum wage calculated on the basis of human capital theory as $8 \%$ of the human capital of each employee. Moreover, the calculation of the minimum wage based on human capital theory was made using the social minimum, which was equal to 889.7 UAH on 1 October 2010. The social minimum is an indicator for determining the cost of maintaining household expenses based on the "basket of goods", the components of which are needed to sustain life (the subsistence minimum) and raise children as well as to maintain a minimum of social bonds. Since the analysis was done on job seekers, who are under pressure of unemployment, their expectations did not relate to the social minimum but rather to the minimum for living or intermediate values. This explains the cause of the minor difference between the minimum wage determined on the basis of human capital theory and the minimum wage determined on the basis of the econometric model. The social minimum was applied in direct calculation of the minimum wage.

\section{Conclusions}

As we can see, nowadays there are enough reasons to conclude that the original research programme in the field of the human capital was formed as a result of economic research that began in the 1990s. The programme is gradual as issues in this area of research become more studied year by year and a wider range of problems finds its theoretical explanation.

The empirical study conducted in the Volodarsk-Volynskii Employment Centre in October 2010 indicates the compatibility of the level of payment for labour, as determined by human capital theory, with the level of wages 
for work of the people interviewed. The level of the minimum wage in Ukraine (according to state law) in comparison to the level of the minimum wage determined on the basis of human capital theory on 1 October 2010 shows large variation, since the percentage of compatibility is only $46.7 \%$. This suggests that the statutory minimum wage does not allow the human capital of an employee to be maintained, let alone increased.

However, the level of the minimum wage based on the econometric model is close to the level of the minimum wage calculated on the basis of human capital theory as $8 \%$ of an employee's human capital. This gives us the opportunity to recap that this econometric model confirms the accuracy of the calculation of the level of basic wages according to human capital theory (wages at this level meet the behaviour of human capital) and can be used to calculate employees' wages.

\section{Bibliography}

Cieślak, I. and Dobija, M. (2007) "Teoretyczne podstawy rachunkowości kapitału ludzkiego" [The theoretical bases for human capital measurement]. Zeszyty Naukowe Uniwersytetu Ekonomicznego w Krakowie 735. Kraków: Cracow University of Economics, pp. 5-24.

Dobija, M. (1997) "Ile powinien zarabiać anestezjolog?" [How much should an anaesthetist earn?]. Master of Business Administration 5.

Dobija, M. (2007) "The Abstract Nature of Capital and Money" in L. M. Cornwall (ed.) New Developments in Banking and Finance. New York: Nova Science Publishers, Inc., pp. 89-114.

Dobija, M. (2009) "Analiza zbieżności gospodarki polskiej i ukraińskiej według zmian produktywności pracy" [Analysis of the convergence between the Polish and Ukrainian economies according to changes in labour productivity] in Konwergencja modeli ekonomicznych. Polska i Ukraina [Convergence of economic models. Poland and Ukraine]. Kraków: Cracow University of Economics Foundation, pp. 107-29.

Dobija, M. (ed.) (2010) Teoria pomiaru kapitału $i$ zysku [The theory of measuring capital and profit]. Kraków: Cracow University of Economics Press.

Dobija, M. (2011a) "The Abstract Nature of Money and the Modern Equation of Exchange”. Modern Economy 2: 142-52, May, doi:10.4236/me.2011.20019.

Dobija, M. (2011b) "Labour Productivity vs Minimum Wage Level". Modern Economy 2: 780-87, doi:10.4236/me.2011.25086.

Dobija, M. (2011c) "Laboryzm. Naukowa programa doslidzen u sferi ludskogo kapitalu i praci". Problemy teorii ta metodologii buhgalterskogo obliku, kontrolu i analizu. Miznarodnyj zbirnyk naukowych prac. Za materialamy X Juwilejnoi Miznarodnoi naukowoi konferencii "Ekologo-socialni orijentyry buhgalterskogo obliku, kontrolu, ekonomicznogo analizu: cywilizacijni wyklyky". Wypusk 3 (21), Czastyna 1. Zytomyr: ZDTU, pp. 119-34. 
Kozioł, W. (2007) "Wykorzystanie analitycznej funkcji produkcji w procesie motywacji placowej" [Using the analytical function of production in the process of wage incentives]. Zeszyty Naukowe Uniwersytetu Ekonomicznego w Krakowie 752. Kraków: Cracow University of Economics.

Kozioł, W. (2010a) "Kształtowanie wynagrodzeń podstawowych nauczycieli akademickich na podstawie pomiaru kapitału ludzkiego i intelektualnego" [The basic pay of university staff on the basis of human and intellectual capital measurement] in M. G. Woźniak (ed.) Nierówności spoteczne a wzrost gospodarczy. Spójność społeczno-ekonomiczna a modernizacja gospodarki [Social inequalities and economic growth. Socio-economic cohesion and the modernisation of the economy]. Paper No. 16. Rzeszów: University of Rzeszów Press.

Kozioł, W. (2010b) Pomiar kapitatu ludzkiego jako podstawa ksztattowania relacji płac $w$ organizacji [Human capital measurement as the basis of wage relations in an organisation]. Doctoral thesis. Kraków: Cracow University of Economics.

Kurek, B. (2008) "The Risk Premium Estimation on the Basis of Adjusted ROA" in I. Górowski (ed.) General Accounting Theory. Evolution and Design for Efficiency. Warsaw: Wydawnictwa Akademickie i Profesjonalne, pp. 375-92.

Kurek, B. (2010) "An Adjusted ROA as a Proxy for Risk Premium Estimation - The Case of Standard and Poor's 1500 Composite Index". Argumenta Oeconomica Cracoviensia 6. Kraków: Cracow University of Economics, pp. 87-103.

Kurek, B. (2011) Hipoteza deterministycznej premii za ryzyko [Hypothesis of the deterministic risk premium]. Monografie: Prace doktorskie [Monographs: doctoral theses] No. 10. Kraków: Cracow University of Economics Press.

Kurek, B. (2012) "An Estimation of the Capital Growth Rate in Business Activities". Modern Economy 3(4): 364-72, July, doi:10.4236/me.2012.34047.

Renkas, J. (2011) "Rozmir ekonomicznoi staloi potencijnogo zrostu ta wstanowlennia za ii dopomogoju minimalnoi zarobitnoi platy dla Ukrainy”. Problemy teorii ta metodologii buhgalterskogo obliku, kontrolu analizu. Miznarodnyj zbirnyk naukowych prac. Serija: Buhgalterskij oblik, kontrol analiz. Wypusk 2 (20). Widpowidalnyj redaktor d.e.n., prof. F. F. Butynec. Zytomyr: ZDTU, pp. 406-13.

Sobczyk, M. (2010) Statystyka opisowa [Descriptive statistics]. Warsaw: C. H. Beck.

Zakon Ukrainy (2009) "Pro wstanowlennia prozytkowogo minimumu ta minimalnoi zarobitnoi platy" wid 20.10.2009 roku No. 1646-VI, http://search.ligazakon.ua/1_doc2. nsf/link1/T091646.html.

\section{Abstract}

\section{Oczekiwania placowe w świetle teorii pomiaru kapitału ludzkiego}

Celem pracy jest zbadanie zgodności płacy oczekiwanej z płacą ustaloną na podstawie stałej ekonomicznej potencjalnego wzrostu. Przeprowadzone badanie umożliwia porównanie ustawowej płacy minimalnej z płacą obliczoną na podstawie teorii kapitału ludzkiego. W tym celu wprowadza się model ekonometryczny zawierający dwie zmienne. Ponadto, dla przejrzystości wywodu, modele pomiaru indywidualnego kapitału ludzkiego są prezentowane wraz z modelami wynagrodzeń godziwych. Uzyskane 
wyniki dowodzą, że przedstawiony w opracowaniu model kapitału ludzkiego może być używany do ustalania płacy godziwej. Wyniki te wnoszą znaczący wkład do dyskusji na temat prawidłowego sposobu pomiaru kapitału ludzkiego i wynagrodzenia godziwego.

Słowa kluczowe: model kapitału ludzkiego, stała ekonomiczna potencjalnego wzrostu, płaca stała, płaca minimalna, oczekiwania płacowe. 